\title{
Peningkatan kompetensi anggota HISPPIKota Tegal dalam penggunaan aplikasi berbasis android
}

\author{
Jatmiko Indriyanto*1, Ida Afriliana ${ }^{2}$, Eko Budi hartono ${ }^{3}$ \\ ${ }^{123}$ Program Studi D3 Teknik Komputer, Politeknik Harapan Bersama \\ e-mail: *3jatmikoindri@yahoo.com, ${ }^{2}$ idaafriharahap@gmail.com, ${ }^{3}$ tara.niscita@gmail.com
}

\begin{abstract}
Abstrak
Program PKM ini bekersama dengan organisasi HISPPI Kota Tegal yang sekretariatnya beralamat di Kelurahan Kemandungan Kota Tegal, yang merupakan perkumpulan himpunan pengajar atau instruktur LKP Kota Tegal. Permasalahan pada organisasi ini adalah organisasi belum tertata baik, kegiatan administrasi belum tertata baik, status keanggotaan dan data keanggotaan masih simpangsiur datanya. Status dan data keanggotaan dibutuhkan untuk oleh dinas pendidikan kota Tegal untuk pendataan, pelatihan dan pemberian bantuan. Kegiatan ini mempunyai tujua nuntuk membenahi pendataan anggota HISPPI melalui aplikasi android yang sudah dibuat dan pelatihan penggunaan aplikasi android.Hampir 95\% anggota HISPPI mengguna kan $\mathrm{hp}$ android, nanti penyebaran aplikasi lewat wadan playstore. Kegiatan ini dilaksanakan dengan dengan metode pengumpulan data, diskusi pemecahan masalah, pelatihan penggunaan aplikasi, dan evaluasi. Luaran akhir yang ingin dicapai dari kegiatan ini adalah meningkatnya kemampuan anggota HISPPI dalam penggunaan aplikasi android dan tertatanya pendataan anggota HISPPI. Kemampuan penggunaan aplikasi android ada peningkatan dari $60 \%$ menjadi $80 \%$. Secara ilmiah, luaran akhir dalam kegiatanpengabdian ini adalah terpublikasinya hasil pengabdian ini dalam jurna lilmiah pengabdian masyarakat.
\end{abstract}

Kata kunci: Program KegiatanMasyarakat, HISPPI, aplikasi android

\section{PENDAHULUAN}

Lembaga Kursus dan Lembaga Pelatihan merupakan dua satuan pendidikan Nonformal seperti yang tertera dalam pasal 26 ayat (4) UU No. 20 tahun 2003 tentang Sistem Pendidikan Nasional. Secara umum dalam pasal 26 ayat (5) dijelaskan bahwa Kursus dan pelatihan diselenggarakan bagi masyarakat yang memerlukan bekal pengetahuan, keterampilan, kecakapan hidup, dan sikap untuk mengembangkan diri, mengembangkan profesi, bekerja, usaha mandiri, dan/atau melanjutkan pendidikan ke jenjang yang lebih tinggi. Selain itu kembali diperlengkapdalam pasal 103 ayat (1) PP No. 17 tahun 2010 tentang pengelolaan dan penyelenggaraan pendidikan bahwa kursus dan pelatihan diselenggarakan bagi masyarakat dalam rangka untuk mengembangkan kepribadian profesional dan untuk meningkatkan kompetensi vokasional dari peserta didik kursus[1].

Program-program yang dapat diselenggarakan oleh lembaga kursus dan pelatihan seperti yang tertuang dalam pasal 103 ayat (2) PP No. 17 tahun 2010 tentang pengelolaan dan penyelenggaraan pendidikan adalah antara lain sebagai berikut:

1. Pendidikan kecakapan hidup;

2. Pendidikan kepemudaan;

3. Pendidikan pemberdayaan perempuan;

4. Pendidikan keaksaraan;

5. Pendidikan keterampilan kerja; 
6. Pendidikan kesetaraan dan / atau;

7. Pendidikan nonformal lain yang diperlukan masyarakat.

Penerapan kemajuan teknologi pada Lembaga Kursus dan Lembaga Pelatihan di Kota Tegal belum digunakan secara efektif, terlihat dari pengelolaan Lembaga Kursus dan Lembaga Pelatihan dan cara penyajian materi di LembagaKetrampilan dan Kursus di Kota Tegal. Pemilik Lembaga Kursus dan Lembaga Pelatihan di Kota Tegal tergabung dalam HISPPI, dengan berbagai bidang.

Dengan latar belakang tersebut maka perlu dilakukan pengabdian masyarakat yang berkaitan dengan pelatihan aplikasi android bagi Anggota HISPPI untuk meningkatkan kompetensinya.

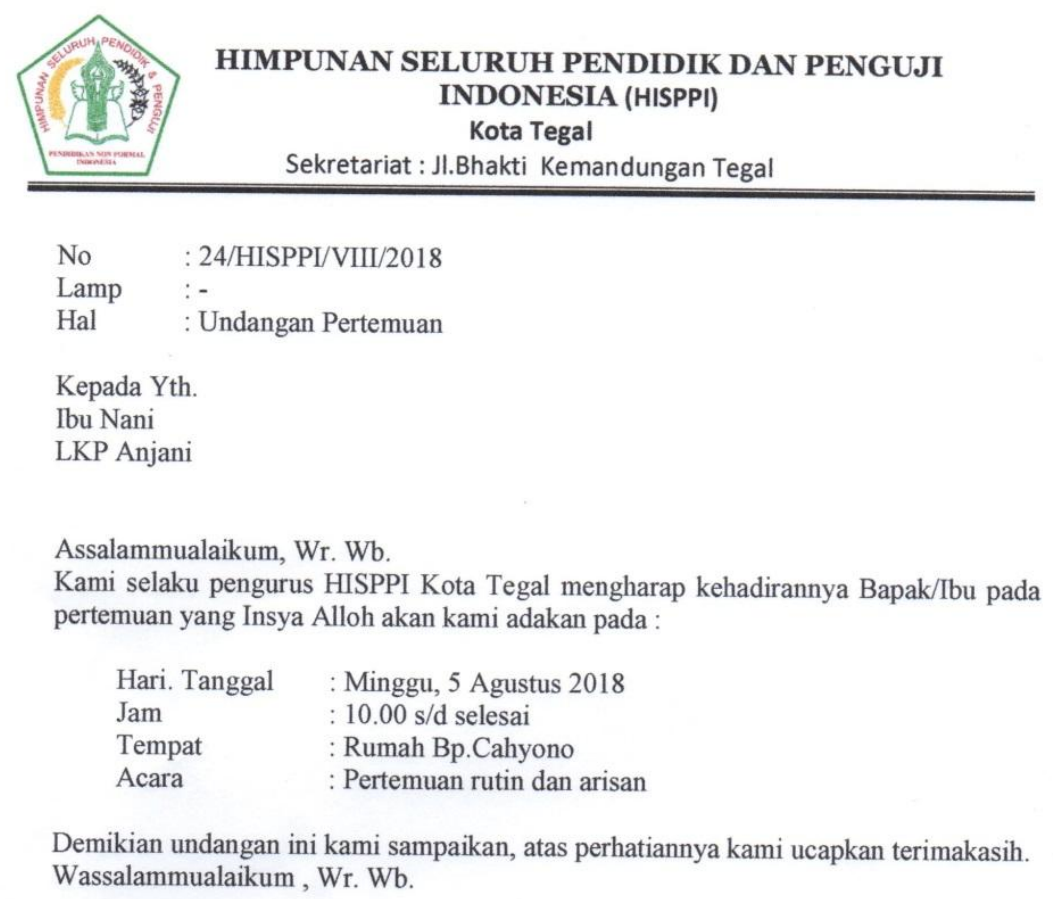

Tegal, 1 Agustus 2018

Ketua

Cahyono, S.Kom

Gambar 1.Undangan Pertemuan Rutin Organisasi HISPPI 


\section{METODE}

\subsection{Sasaran Kegiatan PKM}

Anggota HISSPI, yang terdiri dari instruktur-instruktur LKP Tatarias, computer, menjahit, kerajinan keong, dll, se Kota Tegal.

2.2. Metode Kegiatan

Kegiatan berupa pelatihan penggunaan aplikasi di hp android, dari mulai menghapus aplikasi yang tidak perlu sampai dengan proses memidahkan nomor hp ke hp android yang baru. Selama praktek pelatihan android masing-masing instruktur dibagi membawa laptop dan hp, yang kemudian masing-masing kelompok memperoleh materi android yang sama dengan kelompok lainnya.

\subsection{Kerangka Pemecahan Masalah}

Alternatif pemecahan masalah dilakukan pelatihan penggunaan aplikasi android Para instruktur se Kota Tegal sebagai solusi bagi instruktur untuk menunjang kompetensi keahlian demi mendukung ketercapaian kompetensi instruktur.

2.4. Tahapan Kegiatan PKM

Dalam merealisasikan pemecahan masalah yang dilakukan terdapat beberapa hal yang dilakukan, diantaranya:

2.4.1. Persiapan Kegiatan Pengabdian Masyarakat

Sebelum kegiatan dilaksanakan maka dilakukan persiapan-persiapan sebagaiberikut

(1) Melakukan observasi dan wawancara terhadap kebutuhan instruktur LKP,

(2) Menemukan masalah yang dialami instruktur LKP khususnya kesulitan penggunaan android,

(3) Merancang solusi masalah yang dialami instruktur LKP,

(4) Mempersiapkan kebutuhan untuk pelatihan penggunaan aplikasi android,

(5) Menentukan waktu pelaksanaan dan lamanya kegiatan pengabdianmasyarakat

2.4.2. Pelaksanaan Kegiatan Pengabdian Masyarakat

Adapun kegiatan IbM dalam bentuk pelatihan ini dilaksanakan selama 2 hari dan diikuti oleh 15 peserta pada tanggal 5- 6 Agustus 2018; Waktu pukul 08.00 sampai 14.00 WIB bertempat di secretariat HISPPI Kota Tegal.

2.4.3. Evaluasi kegiatan

Berdsarkan wawancara, Tanya jawab dan pengamatan langsung selama kegiatan pelatihan berlangsung memberikan hasil sebagai berikut memberikan pengetahuan ilmu, meningkatkan ketrampilan dan melatih pemikiran instruktur HISPPI dalam menggunakan aplikasi android.

\subsection{Kegiatanpelatihan}

\section{HASIL DAN PEMBAHASAN}

AdapunMateri yang Disampaikan pada kegiatan pengabdian masyarakat yaitu pengenalan awal system operasi android, pengenalan awal android, perpindahan data antar hp android dan membuka data di hp android yang baru.

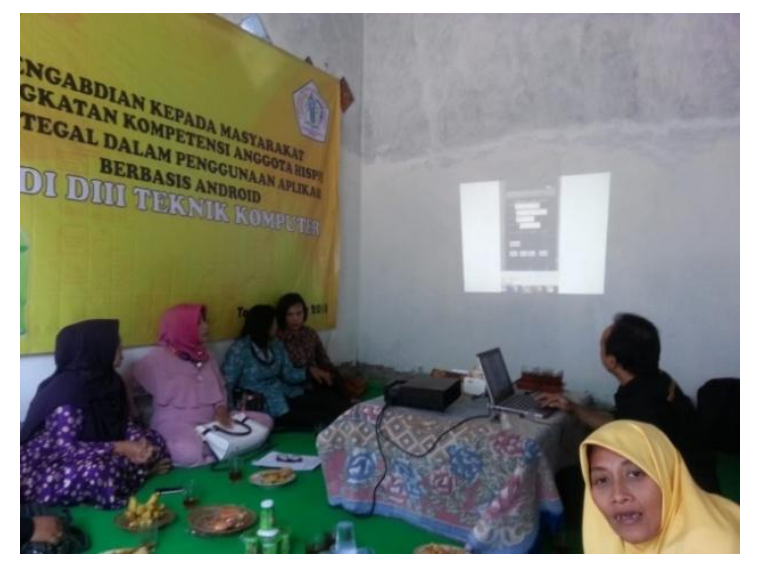

Gambar 2.KegiatanPelatihan 


\subsection{Pendampingan Program}

Dengan metode presentasi dan diskusi serta praktek melalui pendampingan terhadap peserta kegiatan, dengan tujuan output yang dihasilkan instruktur HISPPI mampu menggunakan aplikasi android minimal dasar dan perpindahan datanya. Berbagai kreatifitas pelatihan penggunaan aplikasi android yang dihasilkan dengan materi pengenalan dasar android, backup data \& perpindahan data. Beberapa hal yang menjadi faktor pendukung pada kegiatan pelatihan ini adalah (a) Peserta kegiatan sangat antusias / motivasi mengikuti kegiatan ini sampai selesai, (b) Peserta mempunyai rasa keingin tahuan tinggi terhadap materi ini dan (c) Peserta mau diberikan arahan dan bimbingan saat pelatihan. Adapun Faktor Penghambat pada kegiatan pelatihan ini adalah (a) Waktu kurang memadai, karena pelatihan sangat singkat dengan materi yang cukup padat, (b) Menentukan waktu pelaksanaan pelatihan pembuatan buku ajar dikarenakan berbenturan dengan waktu aktif kuliah mahasiswa, (c) Perlu ada workshop sehingga dapat memberikan pengetahuan lebih jauh tentang penggunaan aplikasi android dan (d) Peserta yang cukup banyak, membuat keadaan cukup berisik.

\subsection{Capaian Kegiatan}

Pelatihan penggunaan aplikasi android merupakan hal baru bagi instruktur LKP HISPPI, berdasarkan wawancara, tanya jawab dan pengamatan langsung terhadap peserta terlihat sangat antusias mengikuti pelatihan ini. Peserta merasa memperoleh informasi pengetahuan baru sebagai bekal kelak mereka ketika menjadi instruktur yang kompeten. Tidak kalah pentingnya, Peserta menyadari bahwa aplikasi android harus berfungsi sebagai penarik minat dan motivasi peserta didik dan pembacanya. Motivasi pembaca bisa timbul karena bahasa yang sederhana, mengalir dan mudah dipahami. Motivasi bisa timbul karena banyak gagasan dan ide - ide baru. Motivasi bisa timbul, karena pelatihan aplikasi android tersebut mengandung berbagai informasi yang relevan dengan kebutuhan belajar instruktur LKP dan pembaca. Namun dalam penelitian ini tidak akan dibahas lebih jauh tentang ini tetapi difokuskan kepada penggunaan aplikasi androidnya saja.
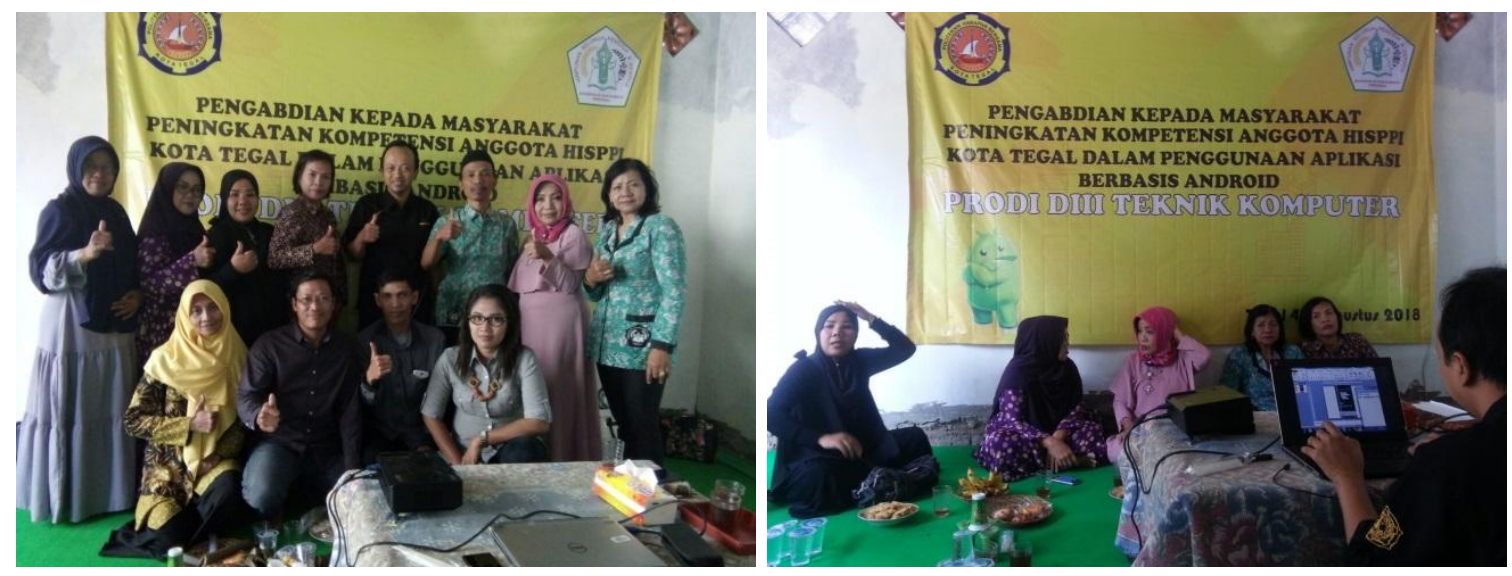

Gambar 3.KegiatanPelatihan

\section{KESIMPULAN}

Adapun hasil kesimpulan kegiatan pengabdian masyarakat sebagai berikut Pelatihan penggunaan aplikasi android padaanggota HISPPI, pemahaman dan penggunaan aplikasi android menjadi lebih baik. Keingintahuan instruktur LKP akan penggunaan aplikasi android bertambah dan mendapatkan respon yang baik dalam mendengarkan pemaparan materi yang disampaikan.

\section{SARAN}

Adapun saran dari hasil kegiatan pengabdian masyarakat sebagai berikut adanya pelatihan yang berkelanjutan, sehingga pemahaman mahasiswa mengenai intrumen lain penunjang pembelajaran selain android seperti komputer, lebih baik lagi. Waktu pelatihan diperpanjang 
sehingga siswa lebih banyak mendapatkan materi tentang pembuatan buku ajar. Pendampingan perlu dilakukan selama pelatihan dan penggunaan aplikasi android. Materi pelatihan android, materinya diperluas lagi.

\section{UCAPAN TERIMA KASIH}

Terimakasih kepada anggota HISPPI Kota Tegal yang sudah menyediakan tempat dan peserta pelatihan, Pusat Penelitian dan Pengabdian Masyarakat (P3M) Politeknik Harapan Bersama tegal yang telah membantu administrasi dan arahan pelatihan kegiatan pengabdian ini.

\section{DAFTAR PUSTAKA}

[1] Undang-Undang Republik Indonesia Nomor 20 tahun 2003 tentang system pendidikan nasional

[2] Buku Panduan Tata Kelola Badan akreditasi Provinsi PAUD danPendidikan Non Formal tahun 2017

[3] Andi S, Tri L, Arief S, Aplikasi android sebagai media alternative promosi produk dan training di pt. djarum berbasis augmented reality, Jurnal SIMETRIS, Vol 6 No 2 November 2015

[2] Puji H, Ishak A, Joni R, Kontribusi Kompetensi Instruktur terhadap hasil belajar Peserta didik Level II Kursus Menjahit di LPK Putra Kencana 2 Bandung, Jurnal Pendidikan Luar Sekolah Volume 1, April 2017

[3] Faiq A, Kualitas Pelayanan Pendidikan Lembaga Kursus dan Pelatihan (LKP) Dian Gitaya, Jurnal Pendidikan Teknik Boga 2017

[4] Ichwani T, Pengelolaan Pembelajaran Berbasis Kualitas di Lembaga Kursus dan Pelatihan Magistra Utama Kota Semarang, Journal of Nonformal Education 2015

[5] Alex S, Pengembangan kemitraan lembaga kursus dan Pelatihan (lkp) dengan dunia usaha dan dunia Industri (dudi) untuk penjaminan mutu LKP, INFOKAM Nomor I Th. XII/MARET/ 2016

[6] Rohmi J, Shohibul K, Mahmuddin Y, Pengembangan aplikasi android sebagai media Pembelajaran matematika pada materi dimensi tiga untuk Siswas makelas x, Malang 2013 